\title{
Pelatihan Penulisan Artikel Ilmiah untuk Pengembangan Karir Guru Matematika di Kabupaten Bojonegoro
}

\author{
Anita Dewi Utami ${ }^{1}$, M. Zainudin 2 , Puput Suriyah ${ }^{3}$, Novi Mayasari ${ }^{4}$, Cahyo Hasanudin ${ }^{5}$, \\ Fathia Rosyida ${ }^{6}$ \\ IKIP PGRI Bojonegoro \\ Email: anita_dewi@ikippgribojonegoro.ac.id,mzainudin@ikippgribojonegoro.ac.id,novi.mayasari@ \\ ikippgribojonegoro.ac.id,puput.suriyah@ ikippgribojonegoro.ac.id, cahyo.hasanudin@ \\ ikippgribojonegoro.ac.id,f.rosyda57@gmail.com
}

\begin{abstract}
The PKM program for writing scientific articles to improve the careers of mathematics teachers in Bojonegoro was carried out through the method of providing training, guidance, and mentoring to participants on how to write articles on the results of classroom action research that was carried out daily in their classrooms to make scientific articles that can be published in journals. The main target audience in this activity were mathematics teachers under the auspices of the Bojonegoro Ministry of Religion, totaling 30 teachers. The area where the training and workshop location was at MAN 2 Bojonegoro is a gathering place for mathematics teachers in the MGMP organization. The results in the PKM program activities were (1) increased knowledge of scientific articles, (2) increased ability and skills of participants in writing scientific articles from the results of classroom action research and (3) participants can integrate scientific writing in the learning process. The outputs of this PKM activity were (1) increasing participants' knowledge of the activity materials, (2) scientific articles published in national seminars or national journals, and (3) publication of PKM implementation on online media.
\end{abstract}

Keyword: Training, Article, Career, Teacher, Mathematics

\begin{abstract}
Abstrak
Program PKM penulisan artikel ilmiah untuk peningkatan karir guru matematika di Bojonegoro dilakukan melalui metode pemberian pelatihan, bimbingan, dan pendampingan kepada peserta mengenai bagaimana cara menulis artikel hasil penelitian tindakan kelas yang dilakukan sehari-hari dalam kelasnya untuk dibuat suatu artikel ilmiah yang dapat terbit di jurnal. Khalayak sasaran utama dalam kegiatan ini yaitu guru-guru matematika di bawah naungan Kemenag Bojonegoro yang berjumlah 30 guru. Wilayah lokasi pelatihan dan workshop di MAN 2 Bojonegoro sebagai tempat berkumpulnya para guru matematika dalam organisasi MGMP. Hasil dalam kegiatan program PKM yaitu (1) meningkatnya pengetahuan mengenai artikel ilmiah, (2) meningkatnya kemampuan dan keterampilan peserta dalam menulis artikel ilmiah dari hasil penelitian tindakan kelas dan (3) peserta dapat mengintergrasikan karya tulis ilmiah dalam proses pembelajaran. Luaran kegiatan PKM ini yaitu (1) meningkatnya pengetahuan peserta mengenai materi-materi kegiatan, (2) artikel ilmiah yang dipublikasikan pada seminar nasional atau jurnal nasional, dan (3) publikasi pelaksanaan PKM pada media online.
\end{abstract}

Kata Kunci: Pelatihan, Artikel, Karir, Guru, Matematika.

\section{PENDAHULUAN}

Pembelajaran yang efektif adalah pembelajaran yang dapat memberikan feedback pada siswa. Pembelajaran efektif yaitu pembelajaran yang berhasil mencapai tujuan belajar (Setyosari, 2017) yang diinginkan (Fakhrurrazi, 2018) dengan memperhatikan kualitas pembelajaran yang dilakukan (Bistari, 2017).

Salah satu yang dapat dilakukan oleh guru dalam memberikan feedback tersebut adalah dengan melakukan Penelitian Tindakan Kelas. Penelitian tindakan kelas (PTK) yang di dalam bahasa Inggris disebut classroom action research (CAR) (MPLP, 2011). PTK bisa memberikan manfaat bagi guru untuk meningkatkan kualitas proses 
pembelajaran dan hasil belajar siswa. Melalui PTK guru bisa menemukan solusi dari permasalahan yang dialami siswa. Selain itu, tugas guru di sekolah selain mengajar adalah sebagai praktisi dan peneliti. Saat ini guru merupakan jabatan profesi yang menuntut adanya sikap profesional dan kemandirian dalam berkarya. Keberadaan status kepegawaian PNS dan Non PNS dapat menjadi informasi yang berguna yang dapat digunakan untuk mengetahui kualitas mengajar dari seorang guru. Karier dari seorang guru PNS ditentukan oleh pangkat dan golongannya, disamping jabatan fungsional lainnya maupun struktural. Golongan tertinggi yang dapat dicapai Guru PNS adalah IVE melalui jabatan fungsional dengan sistem perhitungan angka kredit.

PMPT (2009) telah melakukan penelitian dengan hasil bahwa masih banyak guru yang bergolongan IIA yaitu sebesar 66.337 orang (4.2\%). Kumulatif persentase guru bergolongan II juga masih sekitar 222.043 orang (9\%). Hal tersebut menunjukkan bahwa masih terdapat guru yang pengangkatannya menggunakan kualifikasi setingkat SMA. Jumlah tersebut merupakan pekerjaan tersendiri dalam upaya memenuhi persyaratan yang ditetapkan dalam PP No. 19 Tahun 2005 minimal kualifikasinya S1 atau D4. Namun persentase terbesar ada pada golongan III dengan hampir 49\% yaitu 773.781 orang. Sedang persentase golongan IV mencapai hampir 37\% dengan kontribusi $36.1 \%$ didapatkan dari persentase guru golongan IV/A. Jumlah guru yang IVB keatas tidak lebih dari 15.000 guru. Sangat disayangkan bila mengingat guru dengan golongan IVA sudah mencapai 569.706 orang.

Bila ditelusuri terhambatnya seorang guru pada golongan IVA untuk meningkat ke golongan IV B karena pada tingkatan tersebut persyaratan seorang guru tidak cukup dengan mengumpulkan angka kredit jam mengajar saja, namun masih ada persyaratan yang penting lainnya adalah pengembangan profesi yaitu pengakuan atas kemampuan menulis guru dalam menulis suatu karya ilmiah. Karya ilmiah adalah suatu karangan yang mengandung ilmu pengetahuan dan kebenaran ilmiah yang menyajikan fakta dan disusun secara sistematis menurut metode penulisan dengan menggunakan bahasa ragam ilmiah. Secara ringkas dapat diartikan bahwa pada dasarnya karya ilmiah masalah yang timbul di kelasnya sendiri, bukan kelas orang lain, dengan menerapkan berbagai ragam teori dan teknik pembelajaran yang relevan secara kreatif. Selain itu sebagai penelitian terapan, disamping guru melaksanakan tugas utamanya mengajar di kelas, tidak perlu harus meninggalkan siswanya. Jadi PTK merupakan suatu penelitian yang mengangkat masalah-masalah aktual yang merupakan laporan ilmiah. Laporan yang dimaksud dapat berupa laporan kegiatan ilmiah, kegiatan kajian, dan kegiatan penelitian, baik penelitian lapangan, laboratorium, maupun kepustakaan. Karya ilmiah sebagai laporan kegiatan ilmiah memiliki berbagai jenis, yaitu: makalah, artikel, laporan buku/bab, karya tulis ilmiah, tugas akhir, skripsi, tesis, disertasi, dan buku. Mengapa seorang guru enggan menulis sebuah karya tulis ilmiah. Disamping masalah kemampuan menulis ilmiah, penulisan karya ilmiah memerlukan biaya yang cukup besar dan belum sebanding dengan apa yang akan mereka peroleh setelah golongannya naik ke IVB. Tingginya jumlah guru bergolongan IV/A akan menjadi hal yang menarik untuk diamati berdasarkan karakteristik demografisnya. Tidak tersedianya fasilitas dukungan pembimbing yang memadai, serta minimnya fasilitas informasi akan menjadi beban tersendiri bagi guru yang bertugas pada daerah khusus atau terpencil. Permasalahan di atas menunjukkan belum tuntasnya masalah kompetensi profesional guru. Oleh karena itu, program ini bertujuan untuk mengatasi kesenjangan guru-guru dalam penulisan karya ilmiah yang diterbirkan di jurnal dalam bentuk artikel melalui pelatihan penyusunan karya ilmiah.

Penelitian yang dilakukan oleh Ludiana (2012) menjelaskan bahwa guru masih banyak mengalami kendala dalam penulisan. Sebanyak $67 \%$ guru memiliki hambatan dalam penulisan karya tulis ilmiah jenis diktat/ modul pembelajaran, 58\% guru memiliki hambatan dalam penulisan buku pelajaran, $56 \%$ guru memiliki hambatan 
dalam penulisan artikel ilmiah dan 50\% guru memiliki hambatan dalam penulisan tulisan ilmiah populer.Pengembangan profesionalisme guru dilakukan berdasarkan kebutuhan institusi pendidikan, kelompok guru, dan individu guru sendiri. Menurut Danim (dalam Sa'ud, 2009) bahwa pengembangan guru dimaksudkan untuk merangsang, memelihara, dan meningkatkan kualitas staf dalam memecahkan masalah-masalah keorganisasian. Meski secara tegas dikatakan bahwa pengembangan guru berdasarkan kebutuhan institusi namun hal yang lebih penting dalam pengembangan profesi guru adalah berdasarkan kebutuhan individu guru untuk menjalani proses profesionalisasi. Berhubung substansi kajian dan konteks pembelajaran selalu berkembang dan berubah menurut dimensi ruang dan waktu maka guru dituntut untuk selalu meningkatkan kompetensinya dengan melakukan pengembangan keprofesian berkelanjutan (PKB). Sebagai gambaran guru sekolah masih agak kurang dalam pemahaman penulisan karya tulis ilmiah sehingga tidak dapat mengaplikasikan dengan baik dalam pembelajaran disekolah. Salah satu solusi yang dapat dilakukan yaitu dengan upaya meningkatkan pengetahuan mengenai pelatihan bagaimana cara menulis artikel ilmiah berdasarkan hasil penelitian di kelasnya yang dapat dilakukan dengan Pengabdian Kepada Masyarakat (PKM). Oleh karena itu, Tim Dosen dari Prodi Pendidikan Matematika IKIP PGRI Bojonegoro melakukan kegiatan PKM dengan judul Pelatihan Penulisan Artikel Ilmiah untuk Pengembangan Karir Guru Matematika di Kabupaten Bojonegoro.

\section{METODE}

Metode pelaksanaan program PKM dilakukan secara daring dengan cara memberikan pelatihan dan bimbingan kepada peserta mengenai penulisan artikel ilmiah dari hasil penelitian tindakan kelas. Tujuan pelaksanaan PKM yaitu (1) untuk meningkatkan pengetahuan mengenai artikel ilmiah hasil penelitian tindakan kelas, (2) untuk meningkatkan kemampuan dan keterampilan peserta dalam menulis artikel ilmiah (3) peserta dapat mengintergrasikan hasil penelitiannya dalam proses pembelajaran. Materi yang disajikan dalam program PKM yaitu (1) Teori dan konsep mengenai penulisan artikel ilmiah, (2) Pengembangan dan Implementasi penulisan artikel ilmiah, dan (3) pengintegrasian artikel ilmiah dari hasil PTK dalam penerapan pembelajaran di Sekolah. Kegiatan praktek program PKM disajikan materi praktek penulisan artikel ilmiah. Program pelatihan PKM dilaksanakan berpusat di MAN 2 Bojonegoro pada hari Senin, 2 Agustus 2021 secara luring kemudian dilanjutkan dengan pembimbingan dan pendampingan kepada peserta mulai hari Selasa tanggal 03 Agustus sampai dengan hari Minggu tanggal 15 Agustus 2021 yang dilaksanakan secara daring melalui wa group dan google meet. Khalayak sasaran utama dalam kegiatan ini yaitu guru-guru matematika di Bojonegoro.

\section{PELAKSANAAN DAN HASIL KEGIATAN}

Pelaksanaan kegiatan PkM ini dibagi menjadi tiga tahap, yaitu tahap pra-PKM, pelaksanaan PkM, dan pasca-PkM. Hal ini dapat diuraikan sebagai berikut.

\section{1) Tahap pra-PkM}

Pada tahap pra-PkM tim pengabdi melakukan diskusi untuk menyusun program PKM dan memilih sasaran mitra pengabdian. Pada tahap ini, tim pengabdi sudah merancang konsep yang akan diimplementasikan pada mitra dan media apa saja yang digunakan termasuk media dalam kegiatan ini. selain itu, tim pengabdi juga sudah menyusun materi yang akan disampaikan kepada mitra.

\section{2) Tahap Pelaksanaan PKM}


ABDINE: Jurnal Pengabdian Kepada Masyarakat Vol. 1, No.2, Desember2021,Hal.178-183 p-ISSN 2798-2882, e-ISSN 2798-2890

Program kegiatan PKM ini merupakan kerjasama antara Prodi Pendidikan Matematika IKIP PGRI Bojonegoro dengna MGMP Madrasah Aliyah Kabupaten Bojonegoro. Materi yang disajikan dalam program PKM yaitu (1) Teori dan konsep mengenai penulisan artikel ilmiah, (2) Pengembangan dan Implementasi penulisan artikel ilmiah, dan (3) pengintegrasian artikel ilmiah dari hasil PTK dalam penerapan pembelajaran di Sekolah. Kegiatan praktek program PKM disajikan materi praktek penulisan artikel ilmiah. Program PKM dilaksanakan berpusat di berpusat di MAN 2 Bojonegoro pada hari Senin, 2 Agustus 2021 secara luring kemudian dilanjutkan dengan pembimbingan dan pendampingan kepada peserta mulai hari Selasa tanggal 03 Agustus sampai dengan hari Minggu tanggal 15 Agustus 2021 yang dilaksanakan secara daring melalui wa group dan google meet. Pelaksanaan program PKM mendapat sambutan dan dukungan dari MGMP Madrasah Aliyah Kabupaten Bojonegoro. Partisipasi dan dukungan seperti penyediaan tempat pelaksanaan program PKM dan penyediaan fasilitas kegiatan LCD, meja, papan tulis, printer, dan alat-alat praktek. Narasumber dalam kegiatan program PKM merupakan narasumber ahli di bidang penelitian dan evaluasi pendidikan.

Peserta dalam program PKM sangat antusias dan termotivasi dalam mengikuti kegiatan. Dalam sesi diskusi dan kerja praktek juga ditunjukkan oleh peserta dengan antusiame dan motivasi yang tinggi. Beberapa dokumentasi kegiatan program PKM sebagai berikut:

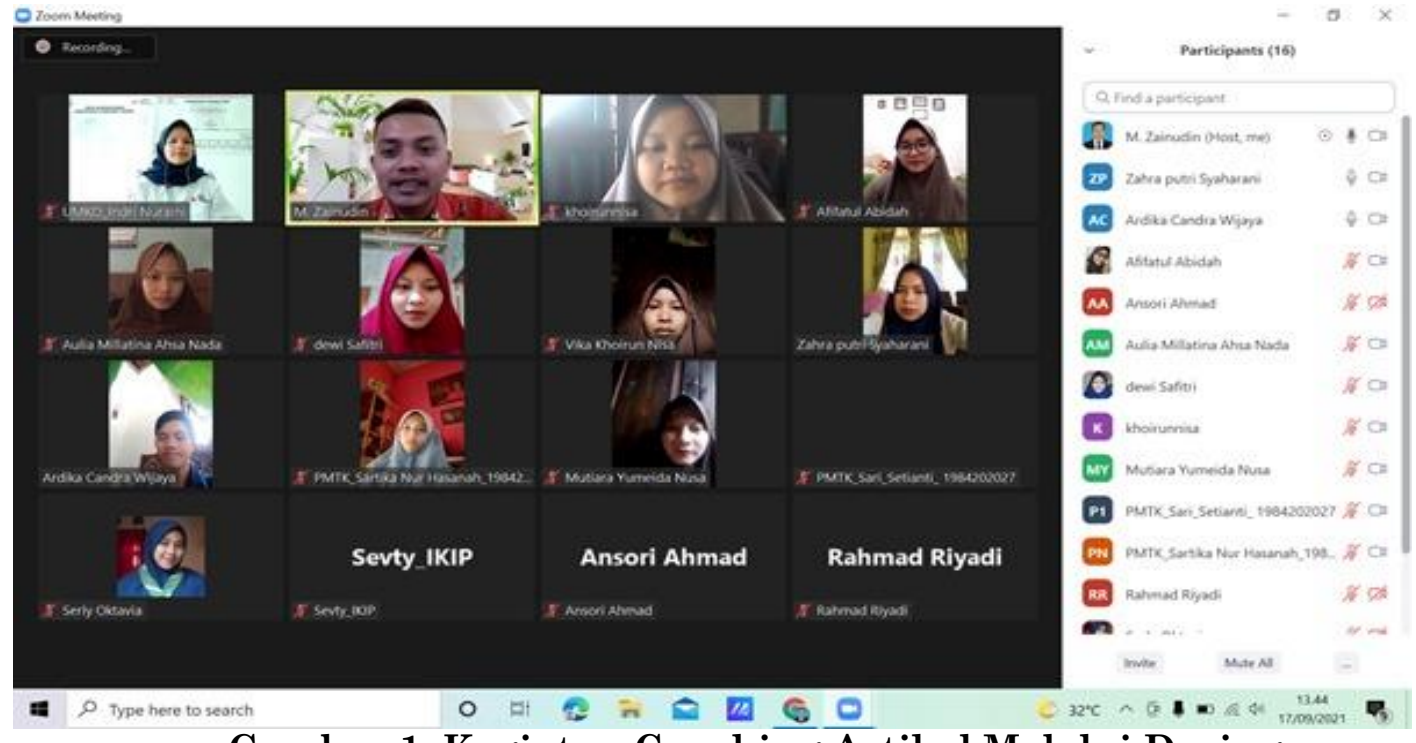

Gambar 1. Kegiatan Coaching Artikel Melalui Daring

\section{3) Tahap Pasca-PkM}

Setelah pelaksanaan $\mathrm{PkM}$, pengabdi memberikan angket untuk diisi oleh mitra. Angket ini untuk mengukur motivasi mitra selama mengikuti pengabdian. Hasil yang diperoleh dalam kegiatan program PKM yaitu meningkatnya motivasi peserta dalam cara pembuatan artikel ilmiah dari jenis kegiatan penelitian selain PTK dan tingginya antusiasme peserta dalam menyebarluaskan atau mendiseminasikan hasil-hasil program PKM terutama materi penulisan artikel ilmiah dan jurnal-jurnal yang ada di Indonesia. Hasil lain yang diperoleh yaitu meningkatnya motivasi peserta dalam mengetahui materi cara mensubmit artikel pada jurnal nasional dan tingginya antusiasme peserta dalam menyebarluaskan atau mendiseminasikan hasil-hasil program PKM terutama materi penyusunan artikel ilmiah. Hal ini dapat dijelaskan pada tabel berikut. 
ABDINE: Jurnal Pengabdian Kepada Masyarakat Vol. 1, No.2, Desember2021,Hal.178-183 p-ISSN 2798-2882, e-ISSN 2798-2890

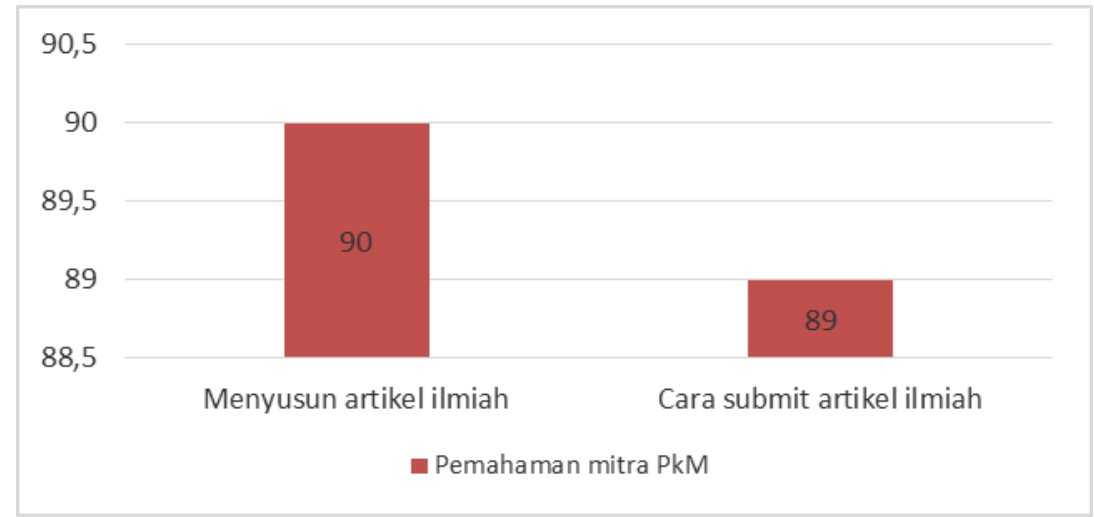

Gambar 2. Hasil postes mitra PkM

Hasil postes selanjutnya dibandingkan dengan hasil pretes. Pembandingan kedua hasil ini bertujuan untuk mengetahui peningkatan pemahaman mitra pengabdian tentang karya ilmiah. Hasil tersebut dapat dilihat pada gambar berikut ini.

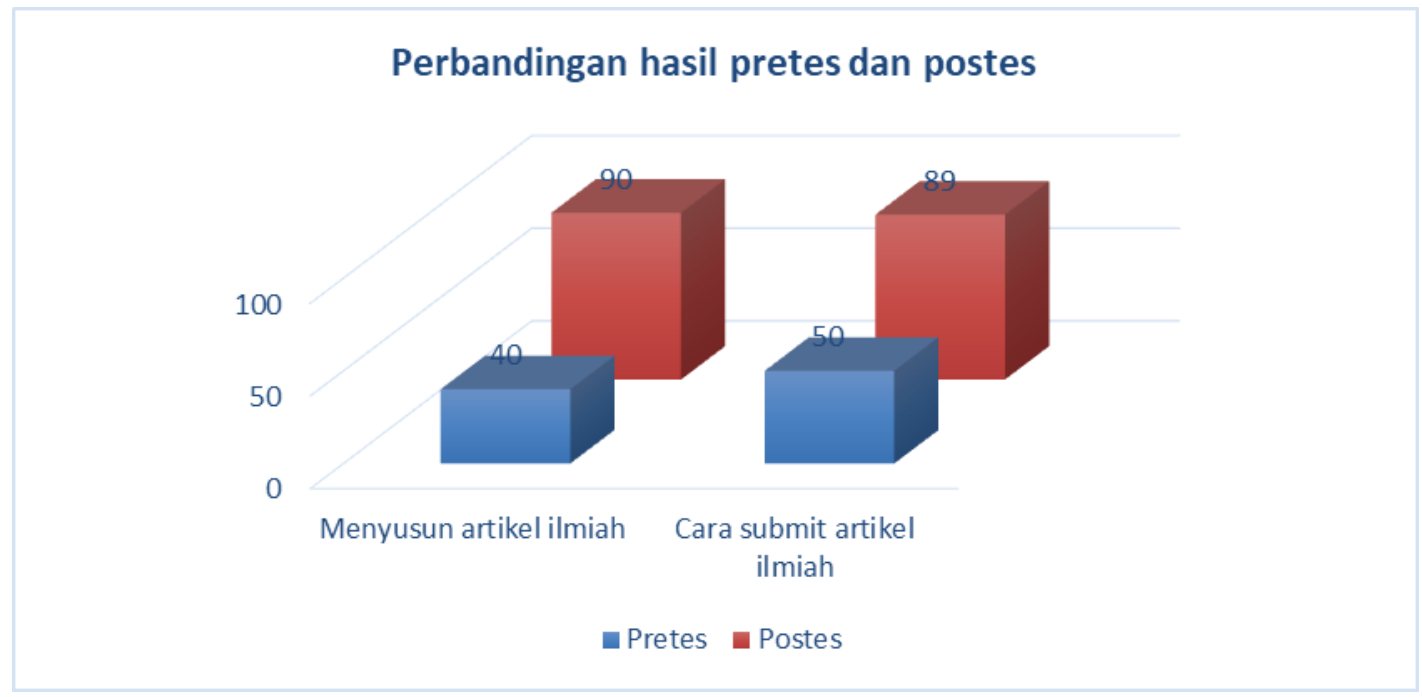

\section{Gambar 3. Perbandingan pretes dan postes mitra PkM}

Hasil PKM ini sejalan dengan hasil program PKM yang dilakukan oleh Alimuddin et al., (2018) dan Purnamawati et al. (2018) yang memperoleh hasil bahwa peserta kegiatan program PKM sangat bersemangat dalam mengetahui materi-materi kegiatan dan bekerja kelompok dalam kegiatan sesi praktek serta menyebarluaskan hasil-hasil pelaksanaan PKM kepada khalayak guru lainnya.

\section{KESIMPULAN}

Kesimpulan dalam pelaksanaan program PKM yaitu 1) peningkatan pemahaman dan keterampilan guru tentang cara menulis artikel ilmiah dari hasil penelitian tindakan kelas sebesar 50\%, dan 2) meningkatnya pemahaman dan keterampilan guru dalam mensubmit artikel ke jurnal berbasis OJS sebesar $39 \%$.

\section{DAFTAR RUJUKAN}

Alimuddin, Mulbar, U., \& Nasrullah. (2018). PKM Pembelajaran Matematika Realistik untuk Guru Sekolah Dasar. 
ABDINE: Jurnal Pengabdian Kepada Masyarakat Vol. 1, No.2, Desember2021,Hal.178-183 p-ISSN 2798-2882, e-ISSN 2798-2890

Bistari, B. (2017). Konsep dan indikator pembelajaran efektif. Jurnal Kajian Pembelajaran Dan Keilmuan, 1(2), 13-20.

Fakhrurrazi, F. (2018). Hakikat pembelajaran yang efektif. At-Tafkir, 11(1), 85-99.

Ludiana, F. (2012). Hambatan Guru Sekolah Dasar Dalam Menulis Karya Tulis Ilmiah Di Kecamatan Kebasen Kota Banyumas. Universitas Negeri Yogyakarta.

MPLP. (2011). Penelitian Tindakan Kelas. UNesa Modul Pendidikan Latihan Profesi Guru, 1(2), 24-36.

PMPT. (2009). Analisis Data Guru 2009. Depdiknas.

Purnamawati, Mulbar, U., \& Zaki, A. (2018). PKM Guru Sekolah di Kecamatan Tinggimoncong Pelatihan Penulisan Karya Tulis Ilmiah untuk Meningkatkan Profesionalisme Guru.

Sa'ud, U. S. (2009). Pengembangan Profesi Guru. Alfabeta.

Setyosari, P. (2017). Menciptakan Pembelajaran yang Efektif dan Berkualitas. JINOTEP (Jurnal Inovasi Dan Teknologi Pembelajaran): Kajian Dan Riset Dalam Teknologi Pembelajaran, 1(1), https://doi.org/http://dx.doi.org/10.17977/um031v1i12014p020 